\title{
SOYBEAN RESPONSE TO STARTER NITROGEN AND Bradyrhizobium INOCULATION ON A CERRADO OXISOL UNDER NO-TILLAGE AND CONVENTIONAL TILLAGE SYSTEMS ${ }^{(1)}$
}

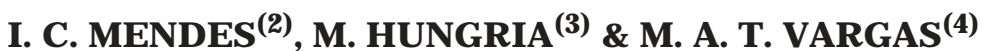

\begin{abstract}
SUMMARY
In Brazil, Bradyrhizobium inoculation has successfully replaced the use of $\mathbf{N}$ fertilizer on soybean [Glycine max (L) Merr.] crops. However, with the expansion of no-tillage cropping systems in the Cerrados region, the idea that it is necessary to use small $\mathbf{N}$ rates at the sowing to overcome problems related with $\mathbf{N}$ immobilization has become widespread, mainly when soybean is cultivated after a non-legume crop. In this study we examined soybean response to small rates of $\mathbf{N}$ fertilizer under no-tillage (NT) and conventional tillage (CT) systems. Four experiments (a completely randomized block with five replicates) were carried out in a red yellow oxisol, during the periods of 1998/1999 and 1999/ 2000, under NT and CT. The treatments consisted of four urea rates $(0,20,30$ and $40 \mathrm{~kg} \mathrm{ha}^{-1} \mathrm{~N}$ ). All treatments were inoculated with Bradyrhizobium japonicum strains SEMIA 5080 and SE MIA 5079, in the proportion $1 \mathrm{~kg}$ of peat inoculant $\left(1,5 \times 10^{9}\right.$ cells $\left.\mathrm{g}^{-1}\right)$ per $50 \mathrm{~kg}$ of seeds. In both experiments, soybean was cultivated after corn and the $\mathbf{N}$ fertilizer was band applied at sowing. In all experiments, $\mathrm{N}$ rates promoted reductions of up to $50 \%$ in the nodule number at 15 days after the emergence. Regardless of the management system, these reductions disappeared at the flowering stage and there was no effect of $\mathbf{N}$ rates on either the number and dry weight of nodules or on soybean yields. Therefore, in the Brazilian Cerrados, when an efficient symbiosis is established, it is not necessary to apply starter $\mathbf{N}$ rates on soybean, even when cultivated under notillage systems.
\end{abstract}

Index terms: soybean, Bradyrhizobium japonicum, inoculation, zero-tillage, biological nitrogen fixation.

(1) Recebido para publicação em janeiro de 2002 e aprovado em outubro de 2002.

(2) Pesquisadora da Embrapa Cerrados. Caixa Postal 8223, CEP 73301-970 Planaltina (DF). E-mail: mendesi@cpac.embrapa.br

(3) Pesquisadora da Embrapa Soja. Caixa Postal 231, CEP 86001-970 Londrina (PR). E-mail: hungria@cnpsoja.embrapa.br

(4) Pesquisador do Bioagri Laboratórios. Caixa Postal 8287, CEP 73301-970 Planaltina (DF). E-mail: mtvargas@uol.com.br 


\title{
RESUMO: RESPOSTA DA SOJ A À ADUBAÇÃO NITROGENADA NA SEMEADURA E INOCULAÇÃO COM Bradyrhizobium EM SISTEMAS DE PLANTIO DIRETO E CONVENCIONAL EM UM LATOSSOLO DA REGIÃO DOS CERRADOS
}

\begin{abstract}
No Brasil a inoculação com rizóbio tem substituído com sucesso o uso de fertilizantes nitrogenados no cultivo da soja. Entretanto, com a expansão do plantio direto na região dos Cerrados, novamente surgiram dúvidas, por parte de alguns agricultores, sobre a efi ciência do processo de inoculação esobrea necessi dade, ou não, da utilização dedoses de "arranque" de adubo nitrogenado na semeadura, visando superar possíveis problemas relacionados à imobilização do $\mathrm{N}$ princi pal mentequando a soj a écultivada após uma cultura não-leguminosa. Foram conduzidos, na Embrapa Cerrados, dois experimentos em áreas sob plantio direto (PD) e dois em áreas sob plantio convencional (PC) visando avaliar a resposta da soja a pequenas doses de $\mathrm{N}$ na semeadura. Os tratamentos consistiram de quatro doses de $\mathrm{N}\left(0,20,30\right.$, e $\left.40 \mathrm{~kg} \mathrm{ha}^{-1} \mathrm{deN}\right)$ na forma de uréia, aplicada na semeadura nosulco deplantio. Emambas as áreas a soja foi cultivada após mil ho. Todos os tratamentos foram inoculados com as estirpes SEMIA 5079 (CPAC 15) e SEMIA 5080 (CPAC 7), na

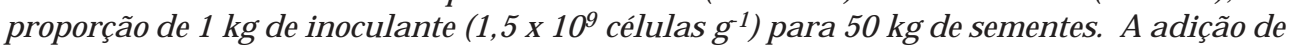
pequenas doses de adubo nitrogenado na semeadura da soja promoveu reduções significativas, deaté50 \%, na sua nodulaçãoinicial, avaliada aos 15 dias após a emergência. Apesar dessa redução, houve uma recuperação no número e massa de nódul os, na fase de floração. Independentemente do sistema de manejo, a adição de pequenas doses de $\mathrm{N}$ na semeadura não promoveu aumentos no rendimento de grãos da soja. Os resultados confirmam que, na região dos Cerrados, quando uma si mbiose efi cienteé estabel ecida, não énecessário adi cionar fertilizanteni trogenado na semeadura da soja, mesmo em áreas sob plantio direto.
\end{abstract}

Termos de indexação: soja, inoculação, Bradyrhizobium japonicum, nitrogênio, plantio direto, fixação biológica.

\section{INTRODUCTION}

Soybean is an annual crop of great importance in Brazil. In the Brazilian Cerrados, which is an edaphic type of savanna covering about $25 \%$ of the country's area, six million hectares were cultivated with this crop in 1999/2000, with an average yield of $2582 \mathrm{~kg} \mathrm{ha}^{-1}$. Amongst the factors responsible for soybean expansion in Brazil, its ability to nodulate and fix $\mathrm{N}$ effectively, with Bradyrhizobium strains, plays a major role. Besides entailing a significant reduction in production costs by replacing the use of nitrogen fertilizer (around US\$ 1 billion yearly), soybean inoculation also reduces the risk of environmental pollution.

Native Cerrado soils do not present indigenous bradyrhizobial populations ableto nodulatesoybeans (Peres \& Vidor, 1980; Vargas \& Suhet, 1980). Therefore, inoculation with nitrogen fixing bacteria is important in order to obtain good yields with low production costs. In the early seventies, when the first soybean fiel ds were established in the Brazilian Cerrados, several limiting factors restricted the success of inoculation. Among them was the absence of commercial inoculants, containing strains adapted to the weathered acid soils of the region, capable of efficiently nodulating the soybean cultivars used during this period. In the late seventies, as a result of several studies (Peres, 1979; Peres \& Vidor, 1980; Vargas \& Suhet, 1980), Bradyrhizobium elkanii strains 29W and SEMIA 587 were released for the production of commercial inoculants. The strain selection program continued and, in 1992, Bradyrhizobium japonicum strains SE MIA 5079 and SEMIA 5080 were recommended for inoculant production in Brazil (Peres et al., 1993; Vargas et al., 1993). These four strains allow the cultivation of soybean in the Brazilian Cerrados without the use of nitrogen fertilizers (Peres, 1979; Peres \& Vidor, 1980, Vargas \& Suhet, 1980, Vargas et al., 1982, 1993; Peres et al., 1993).

However, even after the release of thefirst strains adapted to Cerrado soils, some farmers insisted on the use of starter nitrogen rates. There were concerns that inoculation al one would be insufficient to provide all the nitrogen required for optimal soybean yields. The main argument was that in newly opened Cerrado areas, the incorporation of plant residues with large $\mathrm{C} / \mathrm{N}$ ratios into the soil would promote nitrogen immobilization, reducing the amount of soil $\mathrm{N}$ available for plants. Vargas et al. (1982) showed that theaddition of starter $\mathrm{N}$ was not necessary, even in areas where large amounts of plant residues ( $26 \mathrm{t} \mathrm{ha}^{-1}$ ) had been incorporated 
in the soil. Similar results were observed in the South of Brazil (Hungria et al ., 1997) and other parts of the world (Sij et al., 1979; K outroubras et al., 1998).

In 1998, three million hectares were cultivated under no-tillage (NT) in the Cerrados region (Freitas, 1999). With the expansion of NT cropping systems, there has been a revival of the idea that it is necessary to use small $\mathrm{N}$ rates at sowing to overcome problems related to $\mathrm{N}$ immobilization, mainly when soybean is cultivated after a non-legume crop. In this study we examined the response of inoculated soybean to starter $\mathrm{N}$ rates under no-till (NT) and conventional tillage (CT) systems.

\section{MATERIALS AND METHODS}

\section{Field trials}

Four field experiments were carried out in adjacent areas, two under no-till (NT) and two under conventional tillage (CT) systems, in the Brazilian Cerrados Research Center (Embrapa Cerrados), in Planaltina, Distríto Federal, Brazil. The soil was a clay-loam Red Yellow Oxisol with an established Bradyrhizobium population, ableto nodulatesoybean, estimated at $4.0 \times 10^{4}$ cells g $^{-1}$ of soil. Theareas were cultivated under CT for three years from 1978 on, and then left fallow until 1993, when cultivation under no-tillage and conventional tillage began. The experiments were conducted in 1998/1999 and in 1999/2000. Chemical analyses of soil samples collected from thefour areas before planting, at depths of 0 to $5 \mathrm{~cm}$ and 5 to $20 \mathrm{~cm}$, are presented in table 1 .
Phosphorus and potassium were band applied (250 kg ha-1 of themixture $0-20-20$ in the experiment conducted in 1998/1999 and $400 \mathrm{~kg} \mathrm{ha}^{-1}$ of the same mixture in 1999/2000). In all experiments, soybean was cropped after corn cv. Cargill C-101, which had received $500 \mathrm{~kg} \mathrm{ha}^{-1}$ of the mixture 4-30-16 at planting and $125 \mathrm{~kg} \mathrm{ha}^{-1}$ of $\mathrm{N}$, as urea, split in two applications ( 20 and 33 days after germination). The amount of corn residues produced in the NT and CT areas was around 8,0 tons of dry matter ha-1. In the CT areas, corn residues were plowed into the soil immediately after harvesting, whereas in the NT areas they were left on the soil surface.

In the NT areas, weeds were controlled with glyphosate ( $\left.2.5 \mathrm{~L} \mathrm{ha}^{-1}\right)$ before soybean planting. In the CT areas, soil management and weed control consisted of mol dboard pl owing foll owed by two runs of a disk harrow, and incorporation of trifluralin (1.5 L ha-1) and imazaquim (1.5 L ha-1). Thirty five days after emergence (DAE), all sites received additional post emergence applications of the mixture phluoziphop-P-butil + phomasaphen (1.5 L ha-1).

The experiments were arranged in a completely randomized block with five replicates. Treatments consisted of four urea rates: 0 (control), 0, 20, 30 and $40 \mathrm{~kg} \mathrm{~N} \mathrm{ha}^{-1}$, band applied at sowing. All treatments were inoculated. Plots were $5.0 \mathrm{~m}$ long and consisted of nine rows drawn $45 \mathrm{~cm}$ apart, with 17 seeds $\mathrm{m}^{-1}$ of the soybean cultivars Cel este (experiments carried out in 1998/1999) and EMGOPA 316 (experiments carried out in 1999/2000). Bradyrhizobium japonicum strains SEMIA 5080 (= CPAC 7, same serogroup as CB 1809 and USDA 110) and SEMIA 5079 (= CPAC 15, same serogroup as

Table 1. Chemical soil properties of soil samples collected from the four sites where the experiments were carried out. Results from a composite soil sample collected before planting ${ }^{(1)}$

\begin{tabular}{|c|c|c|c|c|c|c|c|}
\hline Area & $\mathrm{pH} \mathrm{H}_{2} \mathrm{O}$ & Al & $\mathbf{H}+\mathbf{A l}$ & $\mathrm{Ca}+\mathrm{Mg}$ & $\mathbf{P}$ & $\mathbf{K}$ & SOM \\
\hline & \multicolumn{4}{|c|}{$-\mathrm{mmol}_{\mathrm{c}} \mathrm{dm}^{-3}$} & \multicolumn{2}{|c|}{$\mathrm{mg} \mathrm{dm}^{-3}$} & $\mathrm{~g} \mathrm{~kg}^{-1}$ \\
\hline & \multicolumn{7}{|c|}{0 to $5 \mathrm{~cm}$ depth } \\
\hline $\begin{array}{l}\text { NT }{ }^{(2)}(1998 / 99) \\
\text { NT (1999/00) }\end{array}$ & $\begin{array}{l}6,1 \\
5,9\end{array}$ & $\begin{array}{l}0,3 \\
0,1\end{array}$ & $\begin{array}{l}46,8 \\
48,8\end{array}$ & $\begin{array}{l}3,97 \\
3,79\end{array}$ & $\begin{array}{l}10,7 \\
18,5\end{array}$ & $\begin{array}{l}384 \\
335\end{array}$ & $\begin{array}{l}34 \\
38\end{array}$ \\
\hline \multirow[t]{2}{*}{ СТ $(1999 / 00)$} & $\begin{array}{l}5,7 \\
5,8\end{array}$ & $\begin{array}{l}0,2 \\
0,7\end{array}$ & $\begin{array}{l}49,6 \\
54,6\end{array}$ & $\begin{array}{l}2,74 \\
2,46\end{array}$ & $\begin{array}{l}7,8 \\
6,9\end{array}$ & $\begin{array}{l}296 \\
298\end{array}$ & $\begin{array}{l}28 \\
30\end{array}$ \\
\hline & & & & $20 \mathrm{~cm} \mathrm{de}$ & & & \\
\hline $\begin{array}{l}\text { NT }(1998 / 99) \\
\text { NT }(1999 / 00)\end{array}$ & $\begin{array}{l}5,4 \\
5,4\end{array}$ & $\begin{array}{l}1,1 \\
0,9\end{array}$ & $\begin{array}{l}55,4 \\
50,2\end{array}$ & $\begin{array}{l}2,51 \\
2,01\end{array}$ & $\begin{array}{l}5,0 \\
2,5\end{array}$ & $\begin{array}{l}76 \\
88\end{array}$ & $\begin{array}{l}28 \\
29\end{array}$ \\
\hline $\begin{array}{l}\text { CT }(1998 / 99) \\
\text { CT }(1999 / 00)\end{array}$ & $\begin{array}{l}5,8 \\
5,4\end{array}$ & $\begin{array}{l}0,4 \\
1,1\end{array}$ & $\begin{array}{l}51,0 \\
50,4\end{array}$ & $\begin{array}{l}2,70 \\
2,42\end{array}$ & $\begin{array}{l}6,3 \\
3,8\end{array}$ & $\begin{array}{l}128 \\
101\end{array}$ & $\begin{array}{l}29 \\
28\end{array}$ \\
\hline
\end{tabular}

(1) $\mathrm{Ca}, \mathrm{Mg}$ and $\mathrm{Al}$ were extracted with $1 \mathrm{~mol} \mathrm{~L}^{-1} \mathrm{KCl}$ and determined by atomic absorption (Ca and $\mathrm{Mg}$ ) and titration with $\mathrm{NaOH}$ $0.025 \mathrm{~mol} \mathrm{~L}{ }^{-1}(\mathrm{Al})$. $\mathrm{P}$ and $\mathrm{K}$ were extracted using the Mehlich- $1\left(\mathrm{H}_{2} \mathrm{SO}_{4} 0.0125 \mathrm{~mol} \mathrm{~L}^{-1}+\mathrm{HCl} 0.05 \mathrm{~mol} \mathrm{~L}^{-1}\right)$ method, and determined by flame photometry $(\mathrm{K})$ and spectrophotometry using the blue-Mo method (P), SOM = soil organic matter by the Walkley-Black method (EMBRAPA, 1979). ${ }^{(2)} \mathrm{NT}=$ no-tillage. ${ }^{(3)} \mathrm{CT}=$ conventional tillage. 
USDA 123) were applied as a double-strain powdered peat inoculant. The inoculant was prepared from a pure culture of thesestrains, grown in yeast mannitol broth. The broth culture was applied on sterilized peat (whose $\mathrm{pH}$ had been previously raised to 6.5 with $\mathrm{CaCO}_{3}$ ), to reach about $50 \%$ moisture. The mixture was stored for 30 days to mature at room temperature. Plate counts showed $1.5 \times 10^{9}$ cells $^{-1}$ of peat and MPN counts $5 \times 10^{8}$ cells $^{-1}$. I mmediately before planting, the seeds were inoculated with a peat slurry in a $25 \%$ sucrose sticker solution, at a rate of $1 \mathrm{~kg}$ of inoculant per $50 \mathrm{~kg}$ of seeds.

Twelve plants per plot were collected at 15 DAE (days after emergence) to evaluate the number of nodules. At the pre-flowering stage, six plants per plot were collected with a hoe $(20 \mathrm{~cm}$ deep) to determine the number and dry weight of nodules and also for serol ogical analyses. In these samplings, consecutive plants were removed from near the ends of the third and seventh rows of each plot. The root systems were rinsed with tap water, the nodules detached, dried at $72{ }^{\circ} \mathrm{C}$ for $72 \mathrm{~h}$, weighed, and counted.

At harvest, a 4.0 m section was removed from the four central rows of each plot. The harvested seeds were cleaned and weighed, and the yields adjusted to $13 \%$ moisture.

\section{Nodule serotyping}

Nodule serotyping was carried out by immunoagglutination (Vincent, 1970) and antisera prepared against the strains 29W (= SEMIA 5019), SEMIA 587, CB 1809 (SEMIA 586) and SE MIA 566 (same serogroup as USDA 123) as described by Somasegaran \& Hoben (1985). Strains 29W and SEMIA 587 have been used in Brazilian commercial soybean inoculants since 1979, and strains SEMIA 5079 and SEMIA 5080 since 1992. More information about these serogroups has been described earlier by Boddey \& Hungria (1997). Nodule suspensions were prepared in sterile $8,5 \mathrm{~g} \mathrm{~kg}^{-1} \mathrm{NaCl}$ and boiled for 1 hour at $100^{\circ} \mathrm{C}$. For each nodule, agglutination was realized in microtiter trays. A sample of $300 \mu \mathrm{L}$ of the nodule preparation (antigen) was mixed with one drop of theappropriate antiserum, besides the antigen control which contained only the antigen in saline solution. Positive reactions observed through a light source were determined by the formation of white precipitates. Recovery percentages for serogroups 29 W, SEMIA 587, CB 1809 and SEMIA 566 were determined by serotyping 50 nodules selected at random from each plot.

\section{Statistical analyses}

Data were submitted to analyses of variance using the general linear procedure provided by the SAS software package (SAS, 1996). Percentage data were subjected to arc $\sin \sqrt{ } \mathrm{x}$ transformations prior to analysis and the retransformed means were presented. The treatments were compared by the Dunnet test at a probability level of $5 \%$.

\section{RESULTS AND DISCUSSION}

In all four experiments, regardless of the management system, a significant decrease was observed in the number of nodules 15 DAE in treatments receiving $\mathrm{N}$ (Tables 2 and 3 ). Compared to the control treatment, reductions ranged from 15 to $50 \%$, confirming reports that $\mathrm{N}$ fertilizer reduces or delays nodule formation (Allos \& Bartholomew, 1955; Weber, 1966; Beard \& Hoover, 1971; Koutroubras et al., 1998). Mineral $\mathrm{N}$ affects several steps of the nodulation process, e.g., Zhang et al. (2000) observed that $\mathrm{N}$ application reduces isoflavonoid concentration of soybean root systems, probably playing a regulatory rol ein soybean nodule formation. However, in spite of this initial reduction, nodulation was recovered and, as shown in tables 2 and 3 , at the pre-flowering stage, no differences in nodulation were observed among the treatments.

Table 4 presents the serogroup distribution in nodules. Since there was no treatment without inoculation, it is not possible to evaluate the effects of reinoculation on the occurrence of the inoculant strains in the nodules. However, in all experiments, with the exception of the experiment under CT conducted in 1999/2000, concurrently with the increase in $\mathrm{N}$ starter rates, there was a downward trend there was a downward trend in serogroup CB 1809 ocurrence in nodules (this serogroup is the same of the inoculant strain SE MIA 5080). Although this effect was not statistically significant, further research is necessary to determine if this effect is related to a higher sensitivity of this serogroup to mineral N. Similar results were observed by Vargas et al. (2000) in dry beans fertilized with $N$ and inoculated with Rhizobi um tropici strain CI AT 899.

In the NT and CT areas, there was no effect of starter $\mathrm{N}$ rates on grain yields (Tables 2 and 3 ), showing that the $\mathrm{N}$ in the seed cotyledons and soil $\mathrm{N}$ were enough to provide the necessary $\mathrm{N}$ for soybean seedlings to meet their requirements until the beginning of biological $\mathrm{N}$ fixation. However, it should be mentioned that, after cotyledon consumption, inoculated soybean presented a temporary leaf yellowing when grown without starter $\mathrm{N}$. This yell owing disappeared by the fourth week after emergence, and had no effect on soybean yields (Tables 2 and 3 ). Since the seedlings of the treatments with $\mathrm{N}$ seemed more vigorous, this is likely to be one of the reasons for farmers' concerns regarding the need of starter $\mathrm{N}$ rates, and their belief that the use of small rates of $\mathrm{N}$ at sowing may 
Table 2. Effects of starter $\mathbf{N}$ rates on nodulation per plant (nodule number, NN; nodule dry weight, NDW), and on grain yield of the soybean cultivar Celeste grown under no-tillage (NT) and conventional tillage (CT) systems, in 1998/99

\begin{tabular}{|c|c|c|c|c|c|c|c|c|}
\hline \multirow{4}{*}{$\mathbf{N}$ rates $^{(1)}$} & \multicolumn{4}{|c|}{ No-tillage } & \multicolumn{4}{|c|}{ Conventional tillage } \\
\hline & \multicolumn{3}{|c|}{ Nodulation } & \multirow{3}{*}{ Yield(2) } & \multicolumn{3}{|c|}{ Nodulation } & \multirow{3}{*}{ Yield(2) } \\
\hline & \multirow{2}{*}{$\begin{array}{c}15 \text { DAE } \\
\text { NN }\end{array}$} & \multicolumn{2}{|c|}{ Pre-flowering(2) } & & \multirow{2}{*}{$\begin{array}{c}15 \text { DAE } \\
\text { NN }\end{array}$} & \multicolumn{2}{|c|}{ Pre-flowering(2) } & \\
\hline & & $\mathbf{N} \mathbf{N}$ & NDW & & & $\mathbf{N N}$ & NDW & \\
\hline $\mathrm{kg} \mathrm{ha}^{-1}$ & \multicolumn{2}{|c|}{$\mathrm{N}^{\circ}$ plant $^{-1}$} & $\mathrm{mg}$ & $\mathrm{kg} \mathrm{ha}^{-1}$ & \multicolumn{2}{|c|}{$-\mathrm{N}^{\mathrm{o}}$ plant $^{-1}$} & $\mathrm{mg}$ & $\mathrm{kg} \mathrm{ha}^{-1}$ \\
\hline $\begin{array}{r}0 \\
20 \\
30 \\
40\end{array}$ & $\begin{array}{l}24 \mathrm{a} \\
17 \mathrm{~b} \\
12 \mathrm{~b} \\
13 \mathrm{~b}\end{array}$ & $\begin{array}{l}92 \\
77 \\
90 \\
75\end{array}$ & $\begin{array}{l}343 \\
306 \\
341 \\
294\end{array}$ & $\begin{array}{l}3728 \\
3730 \\
3759 \\
3805\end{array}$ & $\begin{array}{l}16 \mathrm{a} \\
11 \mathrm{~b} \\
12 \mathrm{~b} \\
10 \mathrm{~b}\end{array}$ & $\begin{array}{l}54 \\
51 \\
51 \\
57\end{array}$ & $\begin{array}{l}235 \\
200 \\
207 \\
195\end{array}$ & $\begin{array}{l}3284 \\
3006 \\
3217 \\
3229\end{array}$ \\
\hline C.V. (\%) & 24 & $35(2)$ & $26^{(2)}$ & $9,0(2)$ & 17,2 & $22^{(2)}$ & $27^{(2)}$ & $6,5(2)$ \\
\hline
\end{tabular}

${ }^{(1)}$ All treatments were inoculated before planting. ${ }^{(2)}$ Non significant differences were observed among treatments.

Table 3. Effects of starter $\mathbf{N}$ rates on nodulation per plant (nodule number, $\mathbf{N} \mathbf{N}$; nodule dry weight, $\mathbf{N D W}$ ) and on grain yield of the soybean cultivar Emgopa 316 grown under no-tillage (NT) and conventional tillage (CT) systems, in 1999/2000

\begin{tabular}{|c|c|c|c|c|c|c|c|c|}
\hline \multirow{4}{*}{$\mathrm{N}$ rates $(\mathbf{1})$} & \multicolumn{4}{|c|}{ No-tillage } & \multicolumn{4}{|c|}{ Conventional tillage } \\
\hline & \multicolumn{3}{|c|}{ Nodulation } & \multirow{3}{*}{ Yield(2) } & \multicolumn{3}{|c|}{ Nodulation } & \multirow{3}{*}{ Yield(2) } \\
\hline & \multirow{2}{*}{$\begin{array}{c}15 \text { DAE } \\
\text { NN }\end{array}$} & \multicolumn{2}{|c|}{ Pre-flowering ${ }^{(2)}$} & & \multirow{2}{*}{$\begin{array}{c}15 \text { DAE } \\
\text { NN }\end{array}$} & \multicolumn{2}{|c|}{ Pre-flowering(2) } & \\
\hline & & $\mathbf{N N}$ & NDW & & & $\mathbf{N N}$ & NDW & \\
\hline $\mathrm{kg} \mathrm{ha}^{-1}$ & \multicolumn{2}{|c|}{$\mathrm{N}^{\mathrm{o}}$ plant $^{-1}$} & $\mathrm{mg}$ & $\mathrm{kg} \mathrm{ha}^{-1}$ & \multicolumn{2}{|c|}{ - $N^{o}$ plant ${ }^{-1}$} & $\mathrm{mg}$ & $\mathrm{kg} \mathrm{ha}^{-1}$ \\
\hline $\begin{array}{r}0 \\
20 \\
30 \\
40\end{array}$ & $\begin{array}{l}58 \mathrm{a} \\
47 \mathrm{~b} \\
47 \mathrm{~b} \\
40 \mathrm{~b}\end{array}$ & $\begin{array}{r}118 \\
95 \\
129 \\
96\end{array}$ & $\begin{array}{l}359 \\
289 \\
373 \\
274\end{array}$ & $\begin{array}{l}3224 \\
3320 \\
3305 \\
3337\end{array}$ & $\begin{array}{l}46 \\
39 \\
40 \\
40\end{array}$ & $\begin{array}{l}144 \\
119 \\
117 \\
115\end{array}$ & $\begin{array}{l}425 \\
443 \\
413 \\
366\end{array}$ & $\begin{array}{l}3514 \\
3495 \\
3578 \\
3646\end{array}$ \\
\hline C.V. (\%) & 13 & $22^{(2)}$ & $16^{(2)}$ & $6,0(2)$ & $10^{(2)}$ & $32^{(2)}$ & $25(2)$ & $5,5(2)$ \\
\hline
\end{tabular}

${ }^{(1)}$ All treatments were inoculated before planting. ${ }^{(2)}$ Non significant differences were observed among treatments.

improve soybean yields. Lack of responses to starter $\mathrm{N}$ in grain yields were also reported by Sij et al. (1979), in Texas; Vargas et al. (1982), in Brazilian Cerrados; Hungria et al. (1997), in the southern part of Brazil, and Papakosta \& Veresoglou (1989) and Koutroubras et al. (1998) in Greece.

In a study conducted in Minnesota by Lamb et al. (1990), grain yield responses to N, applied and incorporated before planting, were observed in 9 out of 12 field experiments where soil $\mathrm{NO}_{3}-\mathrm{N}$ was less than $90 \mathrm{~kg} \mathrm{ha}^{-1}$. Simanungkalit et al. (1995) also observed positive responses to starter $\mathrm{N}$ rates $(25$ and $50 \mathrm{~kg} \mathrm{ha}^{-1}$ ) in a sandy clay Red Yellow Podzol in Indonesia. In both studies, the soils presented low populations of indigenous $B$. japonicum strains and theinoculation responses were small, indicating that perhaps with the use of more efficient strains, or higher rates of inoculum, responses to $\mathrm{N}$ could have been smaller or even null. In fact, in the study by Lamb et al. (1990), it was pointed out that although they used the double amount of inoculum recommended, there may not have been enough soybean bradyrhizobia appl ied on the seeds to provide a significant population. Starling et al. (1998) observed in Alabama's sandy soils that, under very specific conditions, such as those of late planted doublecropped soybean, starter $\mathrm{N}\left(50 \mathrm{~kg} \mathrm{ha}^{-1}\right)$ was a viable input for increasing grain yield $\left(150 \mathrm{~kg} \mathrm{ha}^{-1}\right.$, on average). 
Table 4. Effects of starter N and inoculation with SEMIA 5079 and SE MIA 5080 strains on serogroup distribution of soybean nodules. Plants were grown under no-tillage (NT) and conventional tillage (CT) systems ${ }^{(1)}$

\begin{tabular}{|c|c|c|c|c|c|c|c|c|}
\hline \multirow{2}{*}{$\mathbf{N}$ rates } & \multicolumn{4}{|c|}{ NT 1998/1999 } & \multicolumn{4}{|c|}{ NT 1999/2000 } \\
\hline & 29w & 587 & 566 & CB1809 & $29 w$ & 587 & 566 & СВ1809 \\
\hline $\mathrm{kg} \mathrm{ha}^{-1}$ & \multicolumn{8}{|c|}{-Serogroup distribution in nodules, $\%$} \\
\hline $\begin{array}{r}0 \\
20 \\
30 \\
40\end{array}$ & $\begin{array}{l}6,6 \\
4,2 \\
5,2 \\
5,7\end{array}$ & $\begin{array}{l}2,1 \\
1,5 \\
3,6 \\
3,6\end{array}$ & $\begin{array}{l}69,5 \\
79,3 \\
76,0 \\
74,0\end{array}$ & $\begin{array}{r}15,6 \\
10,3 \\
9,2 \\
10,8\end{array}$ & $\begin{array}{r}15,9 \\
9,7 \\
11,0 \\
7,8\end{array}$ & $\begin{array}{r}11,4 \\
6,9 \\
14,8 \\
11,8\end{array}$ & $\begin{array}{l}41,4 \\
62,7 \\
50,0 \\
60,9\end{array}$ & $\begin{array}{r}17,8 \\
10,2 \\
10,7 \\
9,7\end{array}$ \\
\hline \multirow[t]{3}{*}{ C.V. (\%) } & 47 & 67 & 9 & 23 & 20 & 40 & 13 & 31 \\
\hline & \multicolumn{4}{|c|}{ СТ 1998/1999 } & \multicolumn{4}{|c|}{ CT 1999/2000 } \\
\hline & $29 W$ & 587 & 566 & CB 1809 & $29 W$ & 587 & 566 & CВ1809 \\
\hline $\begin{array}{r}0 \\
20 \\
30 \\
40\end{array}$ & $\begin{array}{l}17,9 \\
12,6 \\
19,4 \\
18,6\end{array}$ & $\begin{array}{r}11,7 \\
13,3 \\
10,2 \\
8,5\end{array}$ & $\begin{array}{l}45,8 \\
50,8 \\
49,9 \\
51,3\end{array}$ & $\begin{array}{r}11,8 \\
12,7 \\
9,3 \\
6,9\end{array}$ & $\begin{array}{l}22,2 \\
21,2 \\
25,9 \\
18,9\end{array}$ & $\begin{array}{r}9,7 \\
9,4 \\
14,5 \\
11,3\end{array}$ & $\begin{array}{l}57,0 \\
60,3 \\
50,8 \\
59,8\end{array}$ & $\begin{array}{l}6,4 \\
6,9 \\
7,0 \\
7,0\end{array}$ \\
\hline C.V. (\%) & 18 & 23 & 9 & 20 & 20 & 13 & 9 & 55 \\
\hline
\end{tabular}

(1) Differences were not statistically significant.

Therefore, based on literature, it can be seen that soybean yield responses to starter $\mathrm{N}$ fertilization have been extremely variable, depending on the efficiency of Bradyrhizobiumstrains (Simanungkalit et al., 1995), soybean cultivars (Papakosta \& Veresoglou, 1989; Starling et al., 1998), soil $\mathrm{NO}_{3}-\mathrm{N}$ content (Lamb et al., 1990) and $\mathrm{N}$ rates. The combination of these factors make responses to starter $\mathrm{N}$ site-specific, showing that before drawing any conclusions on this subject, conditions under which results were obtained must be clearly specified, as well as any limiting factors. In the studies conducted by Koutroubras et al. (1998) in Greece, where the initial N status of the soil was sufficiently adequate to meet theneeds of the plants, the seed yield of soybean cultivar Williams was not affected by $\mathrm{N}$ rates as high as 120 and $240 \mathrm{~kg} \mathrm{ha}^{-1}$ (half applied before planting and half at full bloom), but plants did respond to Bradyrhizobium inoculation. Provided that mineral $\mathrm{N}$ was not the limiting factor, the authors suggested that the supremacy of symbiotic $\mathrm{N}$ vs. combined $\mathrm{N}$ was related to the fact that symbiotic $\mathrm{N}$ is al ready in the organic reduced form, and hence, more readily available for plant metabolism.

Our results proved once more that, in Brazil, rhizobium symbiosis can guarantee high yields without the need of supplying $\mathrm{N}$ fertilizer. It is noteworthy that if the initial delay in nodulation caused by $\mathrm{N}$ rates had occurred in a soil with low populations of soybean bradyrhizobia, a period of imbalance between $\mathrm{N}$ demand and $\mathrm{N}$ supply could have happened. Therefore, under adverse conditions (such as dry spells right after planting), it is likely that this reduction would have more serious consequences on soybean development and yields.

\section{CONCLUSIONS}

1. In this study, performed in an Oxisol of the Brazilian Cerrados, the use of starter $\mathrm{N}$ did not increase soybean grain yields, regardless of the soil management system. Therefore, under that condition, when an efficient symbiosis is established, it is not necessary to use starter $\mathrm{N}$ rates.

2. Theaddition of small $\mathrm{N}$ rates (up to $40 \mathrm{~kg} \mathrm{ha}^{-1} \mathrm{~N}$ ) at sowing reduced nodulation by up to $50 \%$ at 15 DAE. However, soybean recovered nodulation by the preflowering stage.

\section{ACKNOWLEDGEMENTS}

We thank Osmar Teago, Emilio Taveira, Maria das Dores Silva, OdeteJ ustino, and VildereteAlves for their technical assistance. This study was partially financed by CNPq-PRONEX, Group of Excellence in Nitrogen Fixation (41.96.0884.00). M. Vargas (300204/89-2) and M. Hungria (520396/96-0) acknowledge research scholarships from CN Pq. 


\section{LITERATURE CITED}

ALLOS, H.F. \& BARTHOLOMEW,W.V. Replacement of symbiotic fixation by available nitrogen. Soil Sci., 87:61-66, 1955.

BEARD, B.H. \& HOOVER, R.M. Effect of nitrogen on nodulation and yield of irrigated soybeans. Agron J ., 63:815-816, 1971.

BODDEY, L.H. \& HUNGRIA, M. Phenotypic grouping of Brazilian Bradyrhizobium strains which nodulate soybean. Biol. Fert. Soils, 25:407-415, 1997.

EMPRESA BRASILEIRA DE PESQUISA AGROPECUÁRIA EMBRAPA. Serviço de Levantamento e Conservação do Solos. Manual de métodos deanálise desolos, Rio deJ aneiro, 1979. não paginado

FREITAS, P.L. O Sistema de plantio direto e a sustentabilidade na agricultura. B. Inf. SBCS, 24:25-28, 1999.

HUNGRIA, M.; VARGAS, M.A.T.; CAMPO, R.J . \& GALERANI, P.R.. Adubação nitrogenada na soja? Londrina, Empresa Brasileira de Pesquisa Agropecuária, 1997. 4p. (Comunicado Técnico, 57)

HUNGRIA, M.; VARGAS, M.A.T.; CAMPO, R.J .; CHUEIRE, L.M.O. \& ANDRADE, D.A. The Brazilian experience with the soybean (Glycine max) and common bean (Phaseolus vulgaris) symbioses. In: PEDROSA, F.O.; HUNGRIA, M.; YATES, M.G.; NEWTON, W.E., eds. Nitrogen fixation: from molecules to crop productivity. The Netherlands, Kluwer Academics Publishers, 2000. p.515-518.

KOUTROUBRAS, S.D.; PAPAKOSTA, D.K. \& GAGIANAS, A.A. The importance of early dry matter and nitrogen accumulation in soybean yield. Europ. J . Agron., 9:1-10, 1998.

LAMB, J .A.; REHM, G.W.; SEVERSON, R.K. \& CYMBALUK,T.E . I mpact of inoculation and use of fertilizer nitrogen on soybean production where growing seasons are short. J. Prod. Agric., 3:241-245, 1990.

PAPAKOSTA, D.K. \& VERESOGLOU, D.S. Responses of soybean cultivars to inoculation and nitrogen application in Greece in fields free of Bradyrhizobium japonicum. J . Agron. Crop Sci., 163:275-283, 1989.

PERES, J.R.R. Seleção de estirpes de Rhizobium japonicum e competitividade por sítios de infecção nodular em cultivares de soja [Glycine max (L.) Merrill]. Porto Alegre , Universidade Federal do Rio Grande do Sul, 1979. (Tese de Mestrado)
PERES, J .R.R.; MENDES, I.C.; SUHET, A.R. \& VARGAS, M.A.T. Eficiência e competitividade de estirpes de rizóbio para soja em solos de cerrado. R. Bras. Ci. Solo, 17:357-363, 1993.

PERES, J.R.R. \& VIDOR, C. Seleção de estirpes de Rhizobium japonicum e competitividade por sítios de infecção nodular em cultivares de soja. Agron. Sulriog., 16:205-219, 1980.

SAS INSTITUTE INC. SAS/STAT user's guide, version 6. 12.ed. Cary, 1996. 1686p.

SI , J .W.; TURNER, F.T. \& CRAIGMILES, J .P. Starter nitrogen fertilization in soybean culture. Comm. Soil Sci. Plant Anal., 10:1451-1457, 1979.

SIMANUNGKALIT, R.D.M.; INDRASUMUNAR, A.; HASTUIT, R.D.; PRATIWI, E. \& ROUGHLEY, R.J . Soybean response on nodulation to starter nitrogen and inoculation with Bradyrhizobium japonicum. Indones. J. Crop Sci., 10:2532, 1995.

SOMASEGARAN, P. \& HOBEN, H.J. Methods in legumeRhizobium technology. Niftal, Hawaii, 1985.

STARLING, M.E.; WESLEY WOOD, C. \& WEAVER, D.B. Starter nitrogen and growth habit effects on late-planted soybean. Agron. J., 90:658-662, 1998.

VARGAS, M.A.T. \& SUHET, A.R. Efeito de tipos e níveis de inoculante na soja cultivada em um solo de Cerrado. Pesq. Agropec. Bras., 15:343-347, 1980.

VARGAS, M.A.T.; PERES, J.R.R. \& SUHET, A.R. Adubação nitrogenada, inoculação e épocas de calagem para a soja em um solo sob Cerrado. Pesq. Agropec. Bras. 17:1127-1132, 1982.

VARGAS, M.A.T.; MENDES, I.C.; SUHET,A.R. \& PERES, J.R.R. Fixação biológica do nitrogênio. In:ARANTES, N.E;SOUZA, P.I.M., eds. Cultura da soja nos cerrados. São Paulo, Potafos, 1993. p.159-182.

VARGAS, M.A.T.; MENDES, I.C. \& HUNGRIA, M. Response of field grown bean [Phaseolus vulgaris (L)] to Rhizobium inoculation and $\mathrm{N}$ fertilization in two Cerrados soils. Biol. Fertil. Soils, 32:228-233, 2000.

VINCENT, J.M. Manual for the practical study of root nodule bacteria. Oxford, Blackwell, 1970. 164p.

WEBER, C.R. Nodulating and nonnodulating soybean isol ines:I . Response to applied nitrogen and modified soil conditions. Agron J ., 58:46-49, 1966.

ZHANG, F.; MACE, F. \& SMITH, D.L. Mineral nitrogen availability and isoflavonoid accumulation in the root systems of soybean [Glycinemax (L) Merr.]. J . Agron. Crop Sci., 184:197-204, 2000. 